\title{
The Effect of High or Low Oxygen Affinity Red Cells on Tissue Oxygenation and Myocardial Function in Hypoxic Newborn Lambs with or without Hypercapnia
}

\author{
FRANÇOIS-N. URFER, ${ }^{(30)}$ HARRY BARD, ${ }^{(31)}$ JEAN-CLAUDE FOURON, AND \\ MARIE-REINE VAN AMERINGEN \\ Perinatal and Cardiology Services and Centre de Recherche Pédiatrique de l'Hôpital Sainte-Justine, Department of \\ Pediatrics, University of Montreal, Montreal, Quebec, Canada, H3T IC5
}

\section{Summary}

In order to compare high and low oxygen affinity blood under conditions of severe respiratory failure, the effects of a high or low $P_{50}$ were evaluated in two groups of newborn lambs $\left(P_{50}, 20 \mathrm{mmHg}\right.$ versus $30 \mathrm{mmHg}$ ), under conditions of hypoxic hypoxia $\left(\mathrm{Fio}_{2}, 10 \%\right)$ and hypercapnic hypoxia $\left(\mathrm{FiO}_{2}, 10 \%\right.$ and $\left.\mathrm{FiCO}_{2}, 10 \%\right)$. Data on cardiovascular function, blood gas parameters, and tissue oxygenation were collected under normoxic conditions and during severe hypoxia. During hypoxic hypoxia, a higher arterial oxygen content was noted in the high affinity group throughout the experiment; however, there were no significant differences detected in the remainder of the parameters studied. During hypercapnic hypoxia, the position of the oxygen dissociation curve did not cause any significant differences. When, however, hypercapnic hypoxia was compared to hypoxic hypoxia, there was a significant increase in cardiac output and myocardial contraction during hypercapnia.

\section{Abbreviations}

$\mathrm{HbO}_{2}$, hemoglobin oxygen saturation

$L V$, left ventricle

LVET, left ventricular ejection time

PEP, pre-ejection period

ODC, oxygen dissociation curve

$\mathrm{P}_{\bar{v}} \mathrm{O}_{2}$, venous oxygen tension

Recent studies in our laboratory have shown that a lower mixed venous oxygen tension $\left(\mathrm{P}_{\bar{v}} \mathrm{O}_{2}\right)$ in presence of high $\mathrm{O}_{2}$ affinity red cells occurs in normoxemic newborn lambs and that severe anemic hypoxia is better tolerated in lambs with low affinity blood compared to high affinity blood $(13,26)$. A shift of the ODC to the right is believed to be advantageous at normoxia (13), anemia (26), and mild hypoxia $(1,12,14,18)$; however, it may be maladaptive under conditions of severe hypoxia (11). Early preterm newborn infants who have a high oxygen affinity blood $\left(\mathrm{P}_{50}, 18\right.$ $19 \mathrm{mmHg}$ ) (3) frequently suffer from repiratory failure due to hyaline membrane disease. When the disease is severe they are often intubated and mechanically ventilated. Because hyperbilirubinemia is frequent in these infants, many of them are exchange transfused with adult blood $\left(\mathrm{P}_{50}, 27-28 \mathrm{mmHg}\right)$.

In order to evaluate whether the manipulation of oxygen affinity could result in observable differences in cardiovascular function and tissue oxygenation during severe hypoxia, a study was planned to simulate severe respiratory failure in the neonatal period. Newborn lambs were chosen as an experimental model during the first $48 \mathrm{~h}$ after birth when their blood $\mathrm{P}_{50}$ is similar to that of early preterm newborn infants $(18 \mathrm{mmHg})$ whereas the adult animal's $\mathrm{P}_{50}$ ranges between $32-40 \mathrm{mmHg}(2,3)$. The newborn lamb, after an exchange transfusion with adult sheep blood, would have its
$\mathrm{P}_{50}$ increased so that it is in the range of adult human blood (27 $\mathrm{mmHg}$ ).

\section{MATERIALS AND METHODS}

Twenty-six mixed breed newborn lambs less than $48 \mathrm{~h}$ old were included in this study. Intramuscular diazepam was used as sedation $(0.2 \mathrm{mg} / \mathrm{kg}$ as a loading dose, $0.1 \mathrm{mg} / \mathrm{kg}$ repeated at hourly intervals). Infiltration of lidocaine $2 \%$ provided local anesthesia at catheterization site. In an attempt to maintain constant metabolic demands, the animals were curarized with $d$-tubocurarine $(0.2$ $\mathrm{mg} / \mathrm{kg}$ intravenously), half of this dose being repeated if necessary. They were intubated and mechanically ventilated. Rectal temperature was constantly controlled at $38.5 \pm 0.2^{\circ} \mathrm{C}$.

Polyethylene catheters were positioned in descending aorta and right atrium. A Swan-ganz balloon catheter $5 \mathrm{~F}$ was also placed in the pulmonary artery as described previously $(13,26)$. Statham P23Dc transducers provided pressure curves which were registered on a Grass model 7 paper recorder, giving heart rate, systolic, diastolic, and mean pressure values of both systemic and pulmonary circulations. The position of the catheters was determined by the morphology of the pressure curve. For the right atrium the catheter was advanced until the appearance of atrial extrasystoles. At the end of the experiment the position of all catheters were confirmed at autopsy. The lambs were divided in four groups, two of which had their high affinity red blood cells exchanged for low affinity red blood cells (Fig. 1). This was achieved by a two volume exchange transfusion $(160 \mathrm{ml} / \mathrm{kg})$ of fresh heparinized adult sheep blood. The first series of 12 experiments were carried out to compare the high and low oxygen affinity groups (six animals in each group, IA and $1 \mathrm{~B}$ ) when being ventilated with a gas mixture of $10 \% \mathrm{O}_{2}$ and $90 \% \mathrm{~N}_{2}$. Then another series of similar experiments were carried out with 14 animals (seven animal in each group, 2A and 2B) using a gas mixture of $10 \% \mathrm{O}_{2}, 10 \% \mathrm{CO}_{2}$, and $80 \% \mathrm{~N}_{2}$.

Oxygen content was measured in aorta, right atrium, and pulmonary artery samples using a $\mathrm{Lex} \mathrm{O}_{2}$ con, (Lexington Instrument Corporation, Waltham, MA). Throughout the study, the difference between the $\mathrm{O}_{2}$ content of the pulmonary artery and the right atrium was never greater than $2 \%$, indicating that there was no left-to-right shunt through the ductus arteriosus. Samples obtained from descending aorta and pulmonary artery were used to determine $\mathrm{pH}, \mathrm{PO}_{2}, \mathrm{PCO}_{2}$, hemoglobin concentration and $\mathrm{HbO}_{2}$ using instruments from Instrumentation Laboratory Inc. Lexington, MA (213 blood gas analyser tonometer, 208 gas mixing system, 182 co-oximeter). The expired gas was collected in a spirometer and its $\mathrm{O}_{2}$ concentration was measured with an $\mathrm{O}_{2}$ analyser apparatus S3A (Applied electrochemistry Inc. Sunnyvale, CA). Oxygen consumption per minute $\left(\mathrm{V}_{2}\right)$ could thus be determined. Cardiac output $(\dot{Q})$ was calculated applying the Fick principle and was reported to animal weight $\left(\mathrm{ml} \cdot \mathrm{kg}^{-1} \cdot \mathrm{min}^{-1}\right)$. Total pulmonary and 


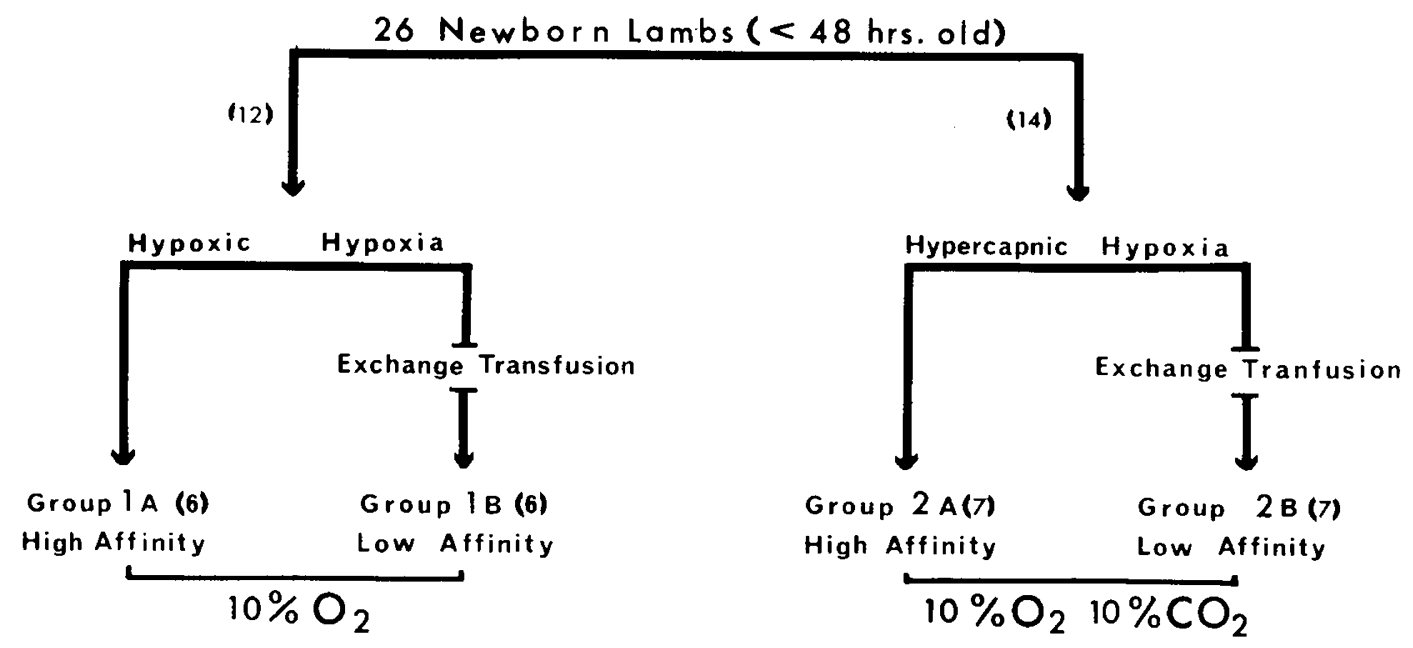

Fig. 1. Schematic representation of the experimental protocol.

systemic resistances (dynes $\cdot \mathrm{sec} \cdot \mathrm{cm}^{-5}$ ) were obtained by dividing the mean pulmonary or aortic pressure with the cardiac output.

During twelve experiments in the hypoxic-hypercapnic groups (six with high and six with low affinity RBCs) and seven experiments in the hypoxic groups (four with high and 3 with low affinity RBC's), the left carotid artery was catheterized with a Millar Mikrotip pressure transducer catheter, which was positioned above the aortic valve. This aortic pressure tracing and an ECG with a well identified $Q$ wave were recorded on photographic paper at a speed of $200 \mathrm{~mm} / \mathrm{sec}$ using a Electronics for Medicine apparatus Model $\mathrm{DR}_{12}$ (Electronics for Medicine White Plains, NY). From five consecutive complexes, the PEP and the LVET were measured as well as the ratio PEP/LVET, which is an accepted index of myocardial contractility. The Mikrotip catheter was also positioned in the LV and the LV pressure signal was processed through a pre-calibrated differentiator model RC-1 giving the $\mathrm{dp} / \mathrm{dt}$ in $\mathrm{mmHg} / \mathrm{sec}$ as another assessment of $\mathrm{LV}$ contractility. At each experimental phase the Mikrotip catheter was successively positioned above and under the aortic valve giving PEP/LVET than $\mathrm{dp} / \mathrm{dt}$.

Heart rate, cardiac output, blood pressures, and vascular resistances of both pulmonarty and systemic circulation, left ventricular $\mathrm{PEP} / \mathrm{LVET}$ and $\mathrm{dp} / \mathrm{dt}, \mathrm{PaO}_{2}, \mathrm{P}_{\overline{\mathrm{v}}}{ }_{2}, \mathrm{PCO}_{2}, \mathrm{pH}, \mathrm{O}_{2}$ content and $\mathrm{P}_{50}$ were measured twice at a basal state (room air), then after 20,45, and $90 \mathrm{~min}$ of hypoxia. All data are expressed as a mean and standard deviation (S.D.). The statistical test used to compare the mean data obtained between the high and low affinity groups was the Student's two sample $t$ test. But when the differences within the same group were compared (control and hypoxic values), a paired $t$ test was used. In order to evaluate the variability of a given lamb, the same data were collected from two different animals for $12 \mathrm{~h}$ under normoxic conditions.

The hemoglobin values $(\mathrm{mg} / 100 \mathrm{ml})$ in the high affinity groups (nonexchange transfused) and the low affinity groups (exchange transfused) were not significantly different. They were $12.1 \pm 1.3$ versus $10.8 \pm 0.7$ and $11.8 \pm 1.4$ versus $10.4 \pm 0.6$ in the hypoxic hypoxia and hypercapnic hypoxia groups respectively.

\section{RESULTS}

Hypoxic hypoxia. The mean $\mathrm{P}_{50}$ increased significantly from $20.4 \pm 2.1$ to $30.3 \pm 1.9 \mathrm{mmHg}$ after exchange transfusion and remained stable until the end of the experiments. In the untransfused lambs the $P_{50}$ remained stable at $21.8 \pm 2.6 \mathrm{mmHg}$. The $\mathrm{PCO}_{2}$ was maintained at $35 \pm 3 \mathrm{mmHg}$ during the experiments. Throughout the hypoxia, the $\mathrm{PaO}_{2}$ decreased significantly but the $\mathrm{pH}$ remained stable $(7.49 \pm 0.04$ for high affinity and $7.47 \pm 0.04$ for low affinity). The $\mathrm{P}^{\mathrm{v}} \mathrm{O}_{2}$ at basal state was significantly lower with high affinity blood in the circulation $(P<0.001)$. During hypoxia, $\mathrm{P}_{\bar{v}} \mathrm{O}_{2}$ decreased with low $(18 \pm 3 \mathrm{mmHg})$ and high $(20$ $\pm 9 \mathrm{mmHg}$ ) affinity RBCs and the difference was no longer significant. There was a rapid decrease in arterial and venous $\mathrm{O}_{2}$ content during hypoxia with a significantly greater arterial $\mathrm{O}_{2}$ content in the high affinity groups, as shown in Figure $2(P<$ 0.005 for high affinity, $P<0.001$ for low affinity).

The arteriovenous difference in $\mathrm{O}_{2}$ content $\left(\mathrm{CaO}_{2}-\mathrm{C} \overline{\mathrm{v}} \mathrm{O}_{2}\right)$, the $\dot{\mathrm{V}} \mathrm{O}_{2}$ and the $\dot{Q}$ of each animal are presented in Figure 3 under normoxic condition and after $20 \mathrm{~min}$ of hypoxia. No significant changes were found between the mean value at 20,45 , and $90 \mathrm{~min}$ of hypoxia. The $\mathrm{VO}_{2}$ decreased significantly for high and low affinity but $\mathrm{CaO}_{2}-\mathrm{Cv}_{2}$ and $\mathrm{Q}$ remained stable.

Pulmonary pressure increased significantly for both groups 34 \pm 8 to $55 \pm 10 \mathrm{mmHg}$ for high affinity and $32 \pm 7$ to $59 \pm 4$ mmHg for the low affinity $(P<0.001)$. The mean pulmonary resistance increased from $2342 \pm 507$ to $3349 \pm 891$ dynes.sec. $\mathrm{cm}^{-5}$ for the high affinity group $(P<0.01)$ and from $2267 \pm 560$ to $3696 \pm 1640$ dynes $\cdot \mathrm{sec} \cdot \mathrm{cm}^{-5}$ for the low affinity group $(P<$ $0.05)$. Systemic pressure did not change $(80 \mathrm{mmHg} \pm 20)$ during hypoxia as did systemic resistance $(5500 \pm 1400$ dynes $\cdot$ sec. $\mathrm{cm}^{-5}$ ). Heart rate did not change significantly and remains at 200 \pm 30 for both groups.

During hypoxic hypoxia the left ventricular mean $\mathrm{dp} / \mathrm{dt} \mathrm{did}$ not vary significantly changing from $3786 \pm 667$ to $4000 \pm 1143$ $\mathrm{mmHg} / \mathrm{sec}$ with high affinity RBCs and from $3162.5 \pm 787$ to $3637 \pm 862 \mathrm{mmHg} / \mathrm{sec}$ with low affinity RBCs group. The PEP/ LVET changed from $0.294 \pm 0.035$ to $0.330 \pm 0.034$ for high affinity group and from $0.284 \pm 0.124$ to $0.240 \pm 0.028$ for low affinity RBCs. These changes were not significant. There were no statistical differences in myocardial function between the high and low affinity groups.

Hypercapnic hypoxia. The mean $\mathbf{P}_{50}$ increased significantly from $18.3 \pm 3.2$ to $29.1 \pm 2.9 \mathrm{mmHg}$ after exchange transfusion and remained stable until the end of the experiment. In the nonexchanged transfused lambs the $P_{50}$ remained stable at $21.4 \pm 2.2$ $\mathrm{mmHg}$. The $\mathrm{PCO}_{2}$ was increased significantly from $35 \pm 3$ to 70 $\pm 5 \mathrm{mmHg}(P<0.001)$. The severe hypercapnic hypoxia induced severe acidosis $(7.47 \pm 0.07$ to $7.1 \pm 0.07$ for the high affinity group and $7.48 \pm 0.07$ to $7.1 \pm 0.04$ for the low affinity). Figure 4 shows that the $\mathrm{P}_{\mathrm{v}} \mathrm{O}_{2}$ was lower with high affinity $\mathrm{RBCs}$ at the basal state $(P<0.05)$ and decreased significantly to similar levels during hypercapnic hypoxia $(17 \pm 2$ for high affinity, $20 \pm 4$ for low affinity). When comparing high affinity to low affinity blood during hypoxic states the $\mathrm{PaO}_{2}$ was significantly higher with low affinity blood $(P<0.02)$. Arterial and venous $\mathrm{O}_{2}$ content decreased significantly $(P<0.001)$ but there was no differences between the low and high affinity groups. Figure 5 illustrates the changes in $\mathrm{CaO}_{2}-\mathrm{C} \overline{\mathrm{vO}}{ }_{2}, \dot{\mathrm{V}} \mathrm{O}_{2}$ and $\dot{\mathrm{Q}}$, which occurred after 20 min of hypercapnic hypoxia. No significant changes were found 


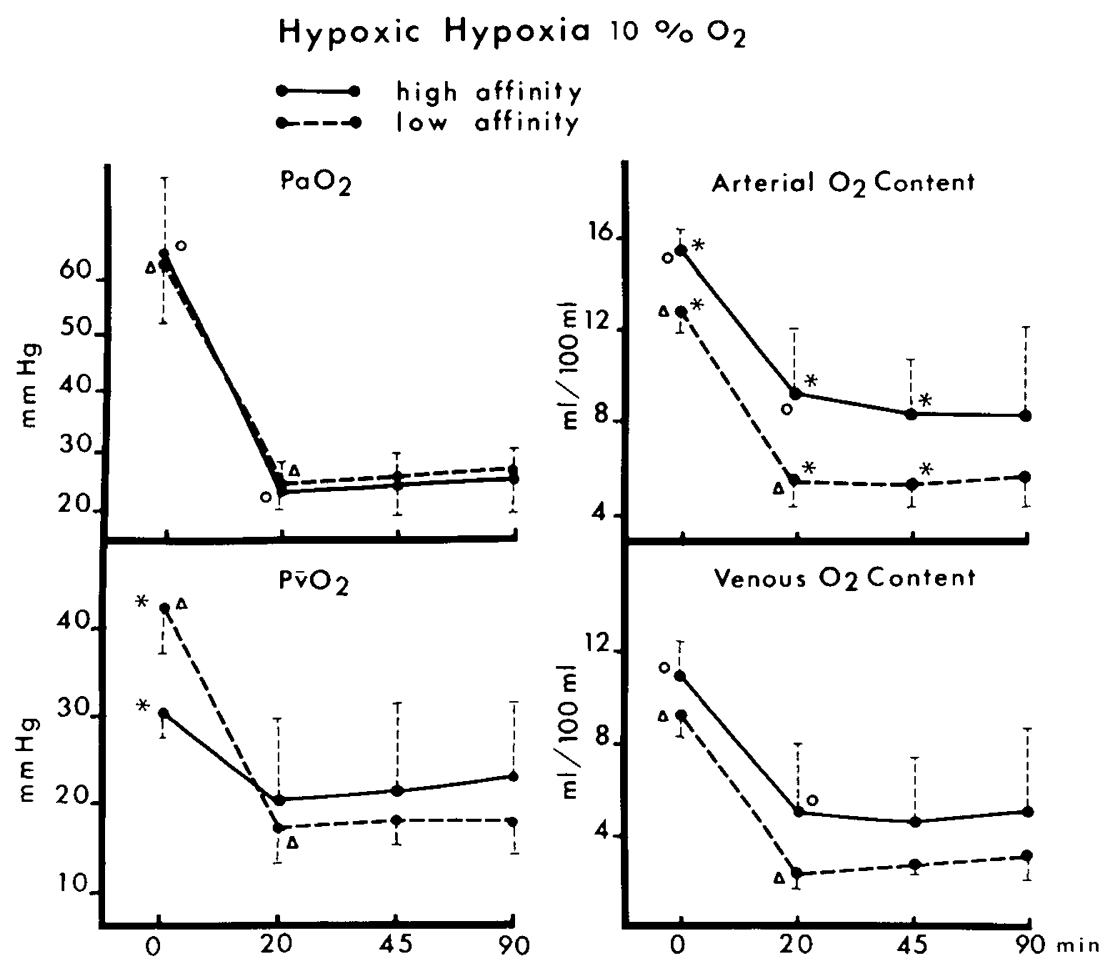

Fig. 2. The $\mathrm{PaO}_{2}$, mixed venous $\mathrm{O}_{2}$ pressure $\left(\mathrm{Pṽ}_{2}\right)$, arterial and venous $\mathrm{O}_{2}$ content are represented at normoxia and after 20,45 , and 90 min of hypoxic hypoxia. The lines join the mean and \pm standard deviation (S.D.) of the newborn lambs with either high or low affinity blood. The notations $O$ and $\triangle$ represent significant differences between control and hypoxia values, whereas * indicates a significant difference between high and low affinity blood groups.

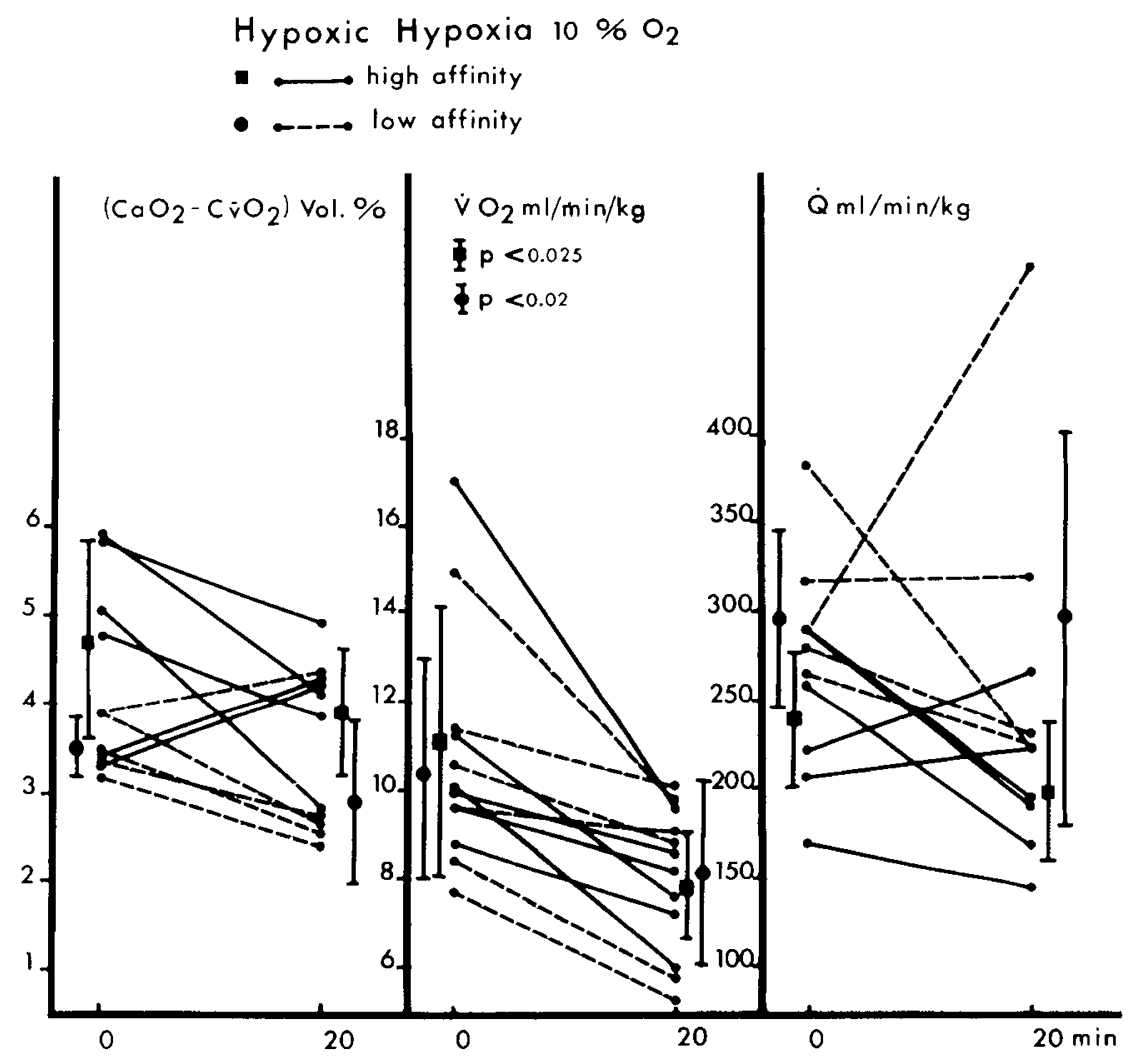

Fig. 3. The $\mathrm{CaO}_{2}-\mathrm{Cv}_{2}, \mathrm{VO}_{2}$ and $\dot{Q}$ are represented for each animal at normoxia and after 20 min of hypoxic hypoxia. The notations $\bullet$ represent the mean \pm standard deviation (S.D.). 
Hypercapnic Hypoxia $10 \% \mathrm{O}_{2} \quad 10 \% \mathrm{CO}_{2}$
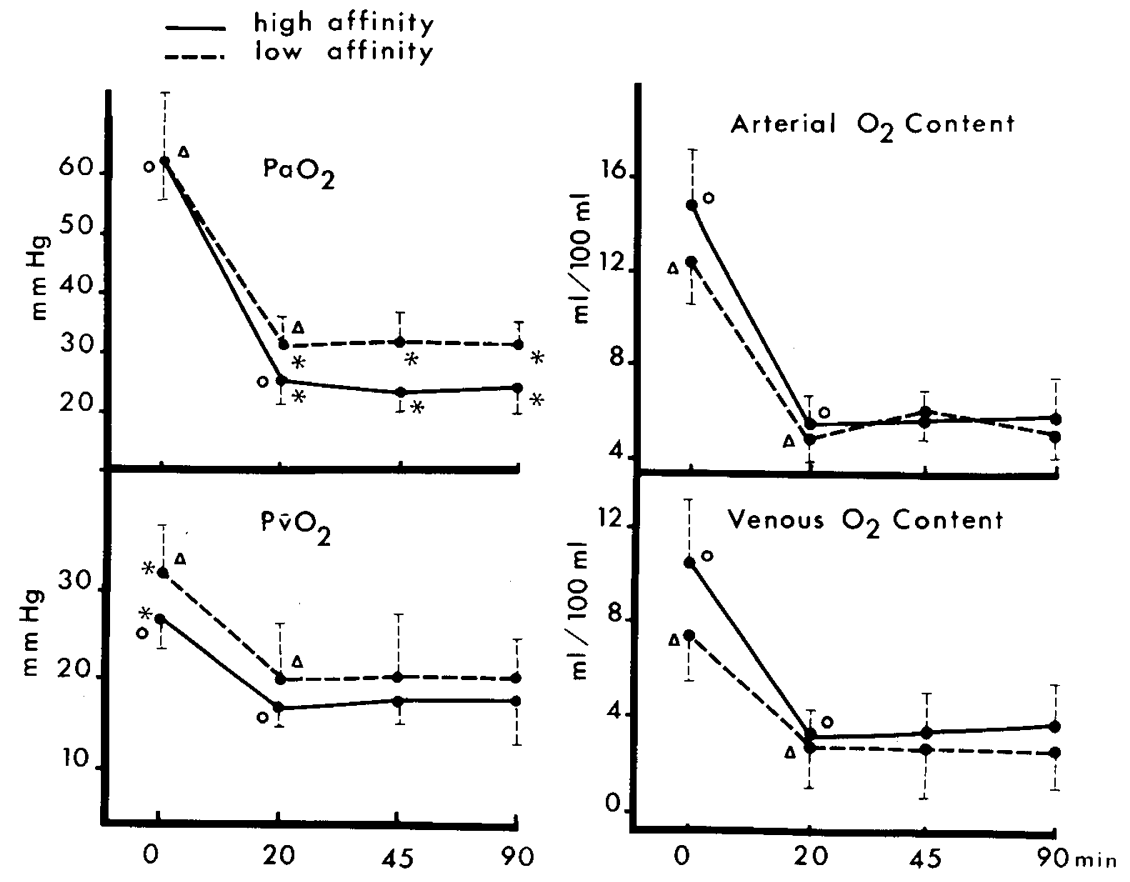

Fig. 4. The $\mathrm{PaO}_{2}$, mixed venous $\mathrm{O}_{2}$ pressure $\left(\mathrm{P}_{\bar{v}} \mathrm{O}_{2}\right)$, arterial and venous $\mathrm{O}_{2}$ content are represented at normoxia and after 20,45 , and 90 min of hypercapnic hypoxia. The lines join the mean and \pm standard deviation (S.D.) of the newborn lambs with either high or low affinity blood. The notations $\bigcirc$ and $\triangle$ represent significant differences between control and hypoxia values, whereas the * indicates a significant difference between high and low affinity groups.

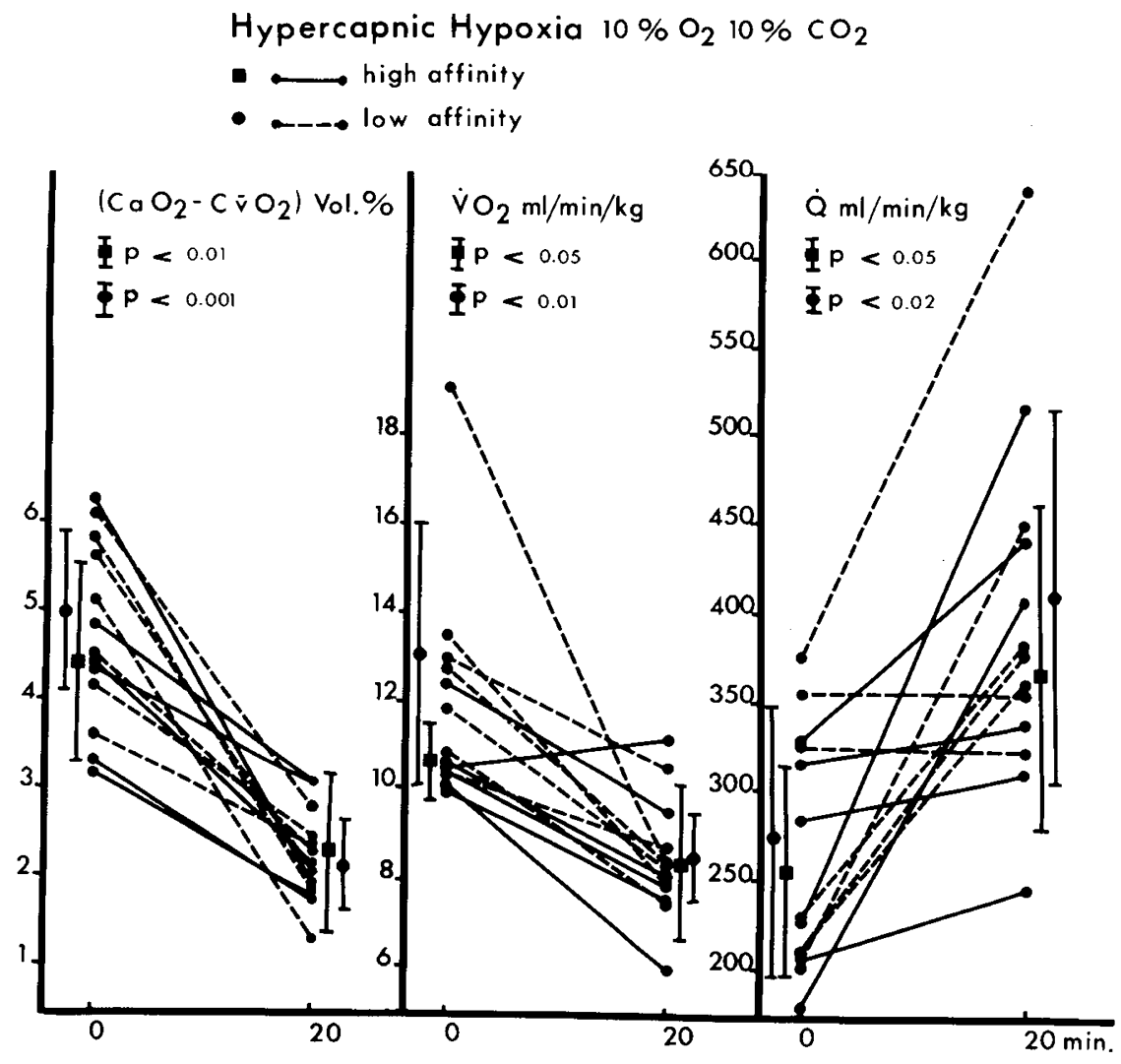

Fig. 5. The $\mathrm{CaO}_{2}-\mathrm{C}_{\bar{v}} \mathrm{O}_{2}, \mathrm{~V}_{2}$ and $\dot{\mathrm{Q}}$ are represented for each animal at normoxia and after 20 min of hypercapnic hypoxia. The notations 9 and represent the mean \pm standard deviation (S.D.). 
between the mean values at 20,45 , and 90 min of hypercapnic hypoxia. The $\dot{\mathrm{VO}}_{2}$ and $\mathrm{CaO}_{2}-\mathrm{Cv}_{2}$ decreased significantly and $\dot{\mathrm{Q}}$ increased significantly.

The mean heart rate increased from $197 \pm 37$ to $238 \pm 18(P$ $<0.025$ ) for the high affinity blood and from $219 \pm 34$ to $243 \pm$ 23 for the low affinity blood (nonsignificant). The pulmonary pressure increased markedly (from $30 \pm 4$ to $60 \pm 8 \mathrm{mmHg}, P<$ $0.001)$ whereas pulmonary resistance increases slightly $(2300 \pm$ 500 to $2800 \pm 700$ dynes $\cdot \mathrm{sec} \cdot \mathrm{cm}^{-5}$, nonsignificant) in both affinity groups. The mean systemic pressure changed little, increasing from 75 to $85 \mathrm{mmHg}$. Systemic resistance decreased significantly $(P<0.05)$ for the high affinity group $(6092 \pm 1126$ to $4096 \pm$ 1109 dynes $\cdot \mathrm{sec} \cdot \mathrm{cm}^{-5}$ ) and nonsignificantly for the low affinity group $\left(5073 \pm 1366\right.$ to $3897 \pm 826$ dynes $\left.\cdot \mathrm{sec} \cdot \mathrm{cm}^{-5}\right)$. But when comparing high and low affinity groups there were no significant differences.

In hypercapnic hypoxia left ventricular $\mathrm{dp} / \mathrm{dt}$ increased significantly from $3693 \pm 1075 \mathrm{mmHg} / \mathrm{sec}$ to $5410 \pm 433$ with high affinity RBCs and from $4482 \pm 1580$ to $5805 \pm 1445$ with low affinity RBCs $(P<0.05)$. The left PEP/ET remained stable, 0.257 \pm 0.054 to $0.261 \pm 0.037$ and $0.280 \pm 0.059$ to $0.308 \pm 0.058$ with high and low affinity blood respectively. There were no difference between the high and low affinity blood groups.

The stability of the preparation used in this study was controlled by measurements taken over a $12-\mathrm{h}$ period in two normoxic animals. The S.D. of serial measurements taken every hour over this period was $4 \%$ of the mean for $\mathrm{V}_{2}, 10.5 \%$ of the mean for $\dot{Q}$ and $8 \%$ of the mean for $\mathrm{CaO}_{2}-\mathrm{Cv}_{2}$, the variation of the other parameters remains under $5 \%$ of the mean. As shown by greater S.D., the variability between our experimental animals during normoxia was more important. The S.D. was $23 \%$ of the mean for $\dot{\mathrm{V}} \mathrm{O}_{2}, 23 \%$ for $\dot{Q}$ and $24 \%$ for $\mathrm{CaO}_{2}-\mathrm{C} \overline{\mathrm{V}} \mathrm{O}_{2}$ and variations of the other parameters remained between $15-20 \%$.

\section{DISCUSSION}

This study provides information on the influence of the position of the ODC upon the oxygenation of the newborn lamb under severe hypoxic hypoxia and severe hypercapnic hypoxia. The animals were lightly sedated, ventilated and curarized in an attempt to maintain constant metabolic demands. The use of sedated and ventilated newborn lambs certainly had its limitations. Cross et al. (5) reported that $\mathrm{V}_{2}$ in nonshivering, nonpanting lambs less than 1-day-old was $12-15 \mathrm{ml} \cdot \mathrm{kg}^{-1} \cdot \mathrm{min}^{-1}$ under normoxic conditions and that it decreases to $6 \mathrm{ml} \cdot \mathrm{kg}^{-1} \cdot \mathrm{min}^{-1}$ under hypoxic conditions $\left(\mathrm{FiO}_{2}, 10-12 \%\right)$. Those values were similar to the $\mathrm{VO}_{2}$ found in this study. Also cardiac output values, as in this study, did not change under hypoxic conditions $(5,6)$. In other studies carried out with unsedated lambs during the first day of life, the reported $\dot{\mathrm{V}} \mathrm{O}_{2}$ and $\dot{Q}$ were either similar (28) or slightly higher than the data reported in this study $(4,19)$. The differences are likely due to the lowered oxygen requirements of the mechanically ventilated newborn lambs reported in this study.

The biologic importance of differences or changes in ODC have been observed between mother and fetus, at altitude, and during hypoxia. The high oxygen affinity of fetal blood suggests that it is designed to facilitate oxygen uptake across the placenta. The comparisons of oxygen transport between different $\mathrm{O}_{2}$ affinity blood in mammals as well as across the pregnant uterus have been reported by Metcalfe and his group $(20,21)$. These authors showed that an evaluation of tissue oxygenation can be made between high and low affinity blood, when the total $\mathrm{O}_{2}$ consumption, $\mathrm{O}_{2}$ content difference between arterial and venous blood as well as the $\mathrm{P}_{\mathrm{v}} \mathrm{O}_{2}$ are determined. The important variable when evaluating oxygen delivery to the tissues is mixed venous $\mathrm{PO}_{2}$. The concept that the level of mixed venous blood tension is a reliable index of tissue oxygenation has been supported by others (25).

In situations of compromised oxygen availability, such as occur in severe red cell mass deficits or poor arterial blood perfusion, a lowered hemoglobin oxygen affinity is of benefit $(9,23,26)$. The changes in oxygen hemoglobin affinity that have been described at moderate altitude remain controversial. It has been accepted by some that there is a decrease in erythrocyte $\mathrm{O}_{2}$ affinity induced by altitude which facilitates oxygen unloading at the tissue level (1, $12,14,18$ ). But Winslow et al. (27) concluded that this shift was offset by compensated respiratory alkalosis with the net results that the ODC position was similar to that of sea level humans. Yet, animals living at high altitude have a higher blood $\mathrm{O}_{2}$ affinity than their lowland relatives (22). Also it has been shown that rat survival at high altitude $(10,000 \mathrm{~m})$ was increased with high affinity hemoglobin in circulation (11) and in a very recent report it was shown that humans having high affinity hemoglobin mutants were better adapted to moderate altitude (16). Thus under conditions of hypoxic hypoxia it may be of greater physiologic importance to have an increase in oxygen binding rather than an increased in oxygen unloading.

In this study, during hypoxic hypoxia, the significant differences noted between high and low affinity can be explained by the respective position of the oxygen dissociation curve. For the same amount of extraction the $\mathrm{P}_{\bar{v}} \mathrm{O}_{2}$ in low affinity group is higher under normoxic conditions. At identical $\mathrm{PaO}_{2}$, the $\mathrm{O}_{2}$ contents of the high affinity groups are higher. But no physiologic differences could be demonstrated by these changes because cardiac output, $\mathrm{VO}_{2}$, and $\mathrm{CaO}_{2}-\mathrm{Cv}_{2}$ between high and low affinity groups were not different. Also the absence of acidosis showed that the minimal $\mathrm{O}_{2}$ requirements during hypoxic hypoxia were maintained irrespectively of the ODC position.

During hypercapnic hypoxia as expected, $\mathrm{V}_{2}$ also decreased significantly; however, unlike the eucapnic group, cardiac output increased probably due to the highly stimulant effect of $\mathrm{CO}_{2}$ on the autonomic nervous system $(10,17,24)$. Therefore for the same decrease in $\mathrm{V}_{2}, \mathrm{CaO}_{2}-\mathrm{C} \overline{\mathrm{V}} \mathrm{O}_{2}$ decreased significantly owing to the increased $\mathrm{Q}$. There is no clear explanation for the significantly high $\mathrm{PaO}_{2}$ in the low affinity group seen during hypercapnic hypoxia. A similar phenomena had been observed by others in hypercapnic low birth weight newborn infants after exchange transfusion (15). A possible speculation is that this finding is the result of a difference in cardiac output as well as pulmonary perfusion.

Although there was a significant decrease in $\dot{\mathrm{V}}_{2}$ in all groups during severe hypoxia, myocardial function was not impaired as shown by the stable $\mathrm{dp} / \mathrm{dt}$ in hypoxic hypoxia. In hypercapnic hypoxia the $\mathrm{dp} / \mathrm{dt}$ increased in both high and low affinity groups. These findings go along well with the increase in $\dot{Q}$. It may well be that a mild hypercapnia by improving $\dot{Q}$ could have a beneficial effect on tissue oxygenation which has been masked by the severe acidosis created by the degree of hypercapnia in this study.

There are several reports and studies which showed that the use of exchange transfusions increased the survival rate of infants of very low birth weight with severe respiratory distress syndrome $(7,8,15)$. The cause of this decrease in mortality remains unclear. The present study shows that from an $\mathrm{O}_{2}$ delivery point of view and myocardial function, the manipulation of red cell oxygen affinity is of no advantage nor disadvantage during severe respiratory failure of the newborn lamb.

\section{REFERENCES AND NOTES}

1. Aste-Salazar, $H$. and Hurtado, A.: The affinity of hemoglobin for oxygen at sea level and at high altitudes. Am. J. Physiol., 142: 733 (1944).

2. Bard, H., Fouron, J. C., Robillard, J. E., Cornet, A., and Soukini, M. A.: Red cell oxygen affinity in fetal sheep: role of 2,3-DPG and adult hemoglobin. J. Appl. Physiol.: Respir. Environ. Exer. Physiol., 45: 7 (1978).

3. Bard, $H$. and Teasdale, F.: Red cell oxygen affinity, hemoglobin type, 2,3diphosphoglycerate and $\mathrm{pH}$ as a function of fetal development. Pediatrics, 64 : $483(1979)$.

4. Berman, W. $J_{r}$. and Musselman $J .:$ Myocardial performance in the newborn lamb. Am. J. Physiol., 237: H66 (1979).

5. Cross, K. W., Dawes, G. S., and Mott, J. C.: Anoxia, oxygen consumption and cardiac output in newborn lambs and adult sheep. J. Physiol., 146: 316 (1959).

6. Dawes, G. S. and Mott, J. C.: The increase in oxygen consumption of the lamb after birth. J. Physiol., 146: 295 (1959). 
7. Delivoria-Papadopoulos, M., Miller, L. D., Forster II., R. E., and Oski, F. A.: The role of exchange transfusion in the management of low-birth-weight infants with and without severe respiratory distress syndrome. I. Initial observations. J. Pediatr., 89: 273 (1976)

8. Delivoria-Papadopoulos, M., Oski, F. A., Miller, L. D., and Forster II., R. E. The pathophysiology of exchange transfusion in the newborn infant with regard to oxygen transport. In: Preservation of Red Blood Cells. pp 137-147. (National Academy of Sciences, Washington D.C., 1973).

9. Dennis, R. C., Vito, L., Weisel, R. D., Valeri, C. R., Berger, R. L., and Hechtman H. B.: Improved myocardial performance following high 2-3 diphosphoglycerate red cell transfusions. Surgery, 77: 741 (1975)

10. Downing, S. E., Mitchell, J. H., and Wallace, A. G.: Cardiovascular responses to ischemia, hypoxia and hypercapnia of the central nervous system. Am. J. Physiol., 204: 881 (1963).

11. Eaton, J. W., Skelton, D., and Berger, E.: Survival at extreme altitude. Protective effect of increased hemoglobin oxygen affinity. Science, 183: 743 (1974)

12. Eaton, J. W., Brewer, G. J., and Grover, R. F.: Role of red cell 2, 3-diphosphoglycerate in the adaptation of man to altitude. J. Lab. Clin. Med., 73: 603 (1969).

13. Fouron, J. C., Bard, H., Le Guennec, J. C., and Van Ameringen, M. R.: Effect of fetal or adult red cells on tissue oxygenation and myocardial function in normoxemic newborn lambs. Pediatr. Res., 15: 967 (1981).

14. Frisancho, A. R.: Functional adaptation to high altitude hypoxia. Science, 187: 313 (1975).

15. Gottuso, M. A., Williams, M. L., and Oski, F. A.: The role of exchange transfusions in the management of low-birth-weight infants with and without severe respiratory distress syndrome. II. Further observations and studies of mechanisms of action. J. Pediatr., 89: 279 (1976).

16. Hebbel, R. P., Eaton, J. W., Kronenberg, R. S., Zanjani, E. D., Moore, L. G. and Berger, E. M.: Human Llamas. Adaptation to altitude in subjects with high hemoglobin oxygen affinity. J. Clin. Invest., 62: 593 (1978).

17. Koehler, R. C., McDonald, B. W., and Krasney, J. A.: Influence of $\mathrm{CO}_{2}$ on cardiovascular response to hypoxia in conscious dogs. Am. J. Physiol., 239 H545 (1980).

18. Lenfant, C., Torrance, J., English, E., Finch, C. A., Reynafarje, C., Ramos, J and Faura, J.: Effect of altitude on oxygen binding by hemoglobin and on organic phosphate levels. J. Clin. Invest., 47: 2652 (1968).

19. Lister, G., Walter, T. K., Versmold, H. T., Dallman, P. R., and Rudolph, A. M.:
Oxygen delivery in lambs: cardiovascular and hematologic development. Am. J. Physiol., 237: H668 (1979)

20. Metcalfe, J., Bartels, H., and Moll, W.: Gas exchange in the pregnant uterus Physiol. Rev., 47: 782 (1967).

21. Parer, J. T., Jones, W. D., and Metcalfe, J.: A quantitative comparison of oxygen transport in sheep and human subjects. Respir. Physiol., 2: 196 (1967)

22. Petschow, D., Wurdinger, I., Baumann, R., Duhm, J., Braunitzer, G., and Bauer, C.: Causes of high blood $\mathrm{O}_{2}$ affinity of animals living at high altitude. J. Appl Physiol., 42: 139 (1977).

23. Rand, P. W., Nelson, C. V., Lacombe, E. H., Barker, N. D., and Pirone, L. A. Application of an isolated heart model to investigate blood-oxygen delivery. Am. J. Physiol., 237: H348 (1979).

24. Tenney, S. M.: Sympatho-adrenal stimulation by carbon dioxide and the inhibitory effect of carbonic acid on epinephrine response. Am. J. Physiol., 187: 341 (1964).

25. Tenney, S. M.: A theoretical analysis of the relationship between venous blood and mean tissue oxygen pressures. Respir. Physiol., 20: 283 (1974).

26. Van Ameringen, M. R., Fouron, J. C., Bard, H., Le Guennec, J. C., and Prosmanne, J.: Oxygenation in anemic newborn lambs with high or low oxygen affinity red cells. Pediatr. Res., 15: 1500 (1981).

27. Winslow, R. M., Monge, C. C., Statham, N. J., Gibson, C. G., Charache, S. Whittembury, J., Moran, O., and Berger, R. L.: Variability of oxygen affinity of blood: human subjects native to high altitude. J. Appl. Physiol., 51: 141 (1981).

28. Woods, J. R., Jr., Dandavino, A., Brinkman III, C. R., Nuwayhid, B., and Assali, N. S.: Cardiac output changes during neonatal growth. Am. J. Physiol., 234; H520 (1978).

29. The authors are grateful for the technical assistance provided by Janie Prosmanne, B.Sc. and Marie-Thérèse Rabeau, B.Sc. They are also very thankful for the cooperation of Lucie C. Lalande and Micheline Raymond in typing the manuscript.

30. Fellow of the Medical Research Council of Canada

31. Requests for reprints should be addressed to: Dr. Harry Bard, Ste-Justine Hospital, 3175 ch. côte Ste-Catherine, Montréal, (Qué.), Canada, H3T 1C5

32. This research was supported by Grant MA-5120 from the Medical Research Council of Canada and in part by the Canadian Heart Foundation.

33. Received for publication December 2, 1981.

34. Accepted for publication November 10, 1982 